\title{
The sustainability of "local" food: \\ a review for policy-makers
}

\author{
Alexander J. Stein ${ }^{1}$ (D) Fabien Santini $^{1}$ \\ Published online: 25 May 2021 \\ (C) INRAE and Springer-Verlag France SAS, part of Springer Nature 2021
}

\begin{abstract}
In the political discussion, the promotion of local food systems and short supply chains is sometimes presented as a means to increase the resilience of the food system, e.g. in the context of the COVID-19 pandemic, and it is also suggested as a means to improve the environmental footprint of the food system. Differentiating between local food systems and short supply chains, a review of the literature on the environmental, social and economic dimensions of sustainability is carried out. "Local food" cannot simply be equated with "sustainable food"; in most cases, it neither can ensure food security nor does it necessarily have a lower carbon footprint. For the environmental sustainability of food systems, many more factors matter than just transportation, not least consumers' dietary choices. In terms of social sustainability, local food systems are not necessarily more resilient, but they can contribute to rural development and a sense of community. In terms of economic sustainability, selling via short supply chains into local markets can benefit certain farmers, while for other producers it can be more profitable to supply international markets.
\end{abstract}

Keywords Local food $\cdot$ Short supply chains $\cdot$ Food systems $\cdot$ Sustainability $\cdot$ Greenhouse gas emissions $\cdot$ Food security

\section{Introduction}

Not least in response to the COVID-19 pandemic, the promotion of local food systems and short supply chains is seen by some policy-makers as a means to increase the

\footnotetext{
Alexander J. Stein

Alexander.STEIN@ec.europa.eu

Fabien Santini

Fabien.SANTINI@ec.europa.eu
}

1 European Commission, Directorate-General for Agriculture and Rural Development, Rue de la Loi 130, 1049 Brussels, Belgium 
resilience of the food system. In this context, and harking back to the concept of "food miles", the promotion of local food systems is also suggested as a means to improve the sustainability of the food system. For instance, during the pandemic, several European countries set up online platforms to give visibility to local food producers and connect them with consumers (ENRD, 2020); the European Committee of the Regions called for the promotion of local food production and of short supply chains, both in the context of the COVID-19 crisis and in view of the sustainability focus of the European Commission's European Green Deal (CoR, 2021); and the European Commission itself acknowledged that calls for shorter supply chains intensified during the COVID-19 pandemic and it announced in its Farm to Fork Strategy that it will support reducing dependence on long-haul transportation to enhance resilience of regional and local food systems (EC, 2020a). At the same time, others warned that overreliance on local production may cause food shortages rather than help addressing food security (Glauber et al., 2020). Therefore, to inform policy-makers and the wider public discussion, we review the existing literature and summarise the evidence on the sustainability of "local" food, covering the environmental, social and economic dimensions of sustainability.

\section{Definition of local food systems and short supply chains}

In the discussion, "local" food systems and "short" supply chains are often used interchangeably, but local food systems can be differentiated from short supply chains. In local food systems "foods are produced, processed and retailed within a defined geographical area" where "the local is always experienced and understood in relation to larger geographical scales, such as the regional, national or global", even if "where the local area ends and another scale begins is subjective, depending on context (density of populations, accessibility and rural or urban character for example) and purpose" (Kneafsey et al., 2013). This means "local" is "the smallest unit used to describe the origin of food" and a consumer is at least "personally familiar with the place where the food is produced" and "would recognise a difference between the terms 'local' and 'regional' when describing the origin of food" (Markuszewska et al., 2012).

By contrast, the term "short" is usually not linked to distance when discussing food systems or food supply chain characteristics. In particular, short supply chains mean chains "involving a limited number of economic operators, committed to co-operation, local economic development, and close geographical and social relations between producers, processors and consumers" (EU, 2013), or even "only supply chains involving no more than one intermediary between farmer and consumer" (EC, 2014). The two concepts are different in the sense that consumers can buy local products via long supply chains (i.e. via several intermediaries) or they can buy products from afar via short chains (e.g. online directly from the producer). Nevertheless, there are overlaps in the sense that local food systems can and do rely on short supply chains and vice versa.

Another related concept is food self-sufficiency, which "is generally taken to mean the extent to which a country can satisfy its food needs from its own domestic production" (Thomson \& Metz, 1998). This production can nevertheless be traded, as long as it could satisfy domestic needs; this is what differentiates self-sufficiency 
from autarky (Clapp, 2017). Clearly, local food systems may or may not be more or less food self-sufficient, depending on their production capacity, but in most countries today hardly ever autarkic. The spatial aspect of where food comes from is covered by the concept of foodsheds, which determines "the geographic area from which a population derives its food supply" (Peters et al., 2009; Schreiber et al., 2021), and which is in general larger than the local area where a population lives. While there is an obvious overlap of the concepts and a certain definitional fuzziness also in the literature, and while we therefore also surveyed literature covering all these concepts, in the following, we try to distinguish between the terms and to use them in accordance with the definitions provided here.

\section{Sustainability of local food systems}

\section{Environmental sustainability}

\section{Greenhouse gas emissions}

In the general discussion, local food is most often linked to sustainability via the concept of "food miles", i.e. the idea that transport-related emissions are so important that they can be used to determine a product's "carbon footprint". By extension, the suggestion is that local food is more sustainable because it is transported less. While this idea might be intuitive at first glance, it ignores the fact that there are many elements that impact a product's carbon footprint more than transportation, such as land use, production processes or storage (Ritchie \& Roser, 2020). Farmers who operate in more favourable environments and are more productive may therefore be able to compensate for the greater "food miles" of their produce.

The carbon footprint of food systems is much more influenced by consumers' dietary choices than by the "localness" of the food they buy (Benis \& Ferrão, 2017; Carlsson-Kanyama \& González, 2009; Ritchie, 2020; Webb et al., 2013). Even eating more seasonal food, another common proposition to decrease the carbon footprint of food, is only another element of a sustainable diet that is overshadowed by the greater environmental and health benefits of dietary change, in particular to reduce overconsumption of meat (Macdiarmid, 2014). Similarly, carbon footprint reductions in local food systems can mainly be achieved with a reduction in animal source foods (Puigdueta et al., 2021).

Even when only looking at transportation, "localness" can be a poor guide to determine a product's carbon footprint as, e.g., cargo ships or trains can exploit economies of scale and be relatively less polluting over longer distances than small trucks over shorter distances (Bell \& Horvath, 2020; Schmitt et al., 2017; Tasca et al., 2017). Similarly, if consumers visit individual local producers, their carbon emissions can be greater than the emissions from the systems of large-scale suppliers (Coley et al., 2009). In short, it seems to be impossible to state that because of their localness, local food systems produce lower emissions compared to conventional ones (Paciarotti \& Torregiani, 2021).

Therefore, in the literature, there is general agreement that "local" cannot be used as a proxy, let alone a guarantee, for lower greenhouse gas emissions (Table 1). “'Longer' 
supply channels generate lower environmental impacts" in terms of carbon footprint (Malak-Rawlikowska et al., 2019), and "long food supply chains may generate less negative environmental impacts than short chains (in terms of fossil fuel energy consumption, pollution, and GHG emissions)... environmental impacts of the food distribution process are not only determined by the geographical distance" (Majewski et al., 2020). In fact, transport-related GHG emissions represent only 5-6\% of total GHG emissions of global food production (Crippa et al., 2021; Ritchie \& Roser, 2020). The notable exception where transport can indeed be used as an indicator for a product's poor carbon footprint is food that is transported by plane (Carlsson-Kanyama \& González, 2009; Schwarz et al., 2016).

\section{Other environmental impacts}

Also in terms of other environmental impacts, local food systems are not necessarily more sustainable than systems that operate at larger scales. For instance, local food systems may require more intensive farming to produce enough food to satisfy the local demand, but while agricultural intensification can ensure greater productivity, it also causes environmental stresses (Pradhan et al., 2015). If instead cropland was expanded, also such an expansion has negative impacts on biodiversity and ecosystem services (Pradhan et al., 2014). For instance, in the USA, localising maize production would cause a 2.7 million ton increase in fertiliser applications and a 50 million pound increase in pesticide use per year, while the required conversion of local natural land to agricultural uses would jeopardise biodiversity (Sexton, 2009). Also regarding these other impacts, the methods of production and of processing are important for ensuring less environmental impact; "local" or "short" is not necessarily better (Kneafsey et al., 2013).

On the other hand, local food systems that rely on short supply chains may require less packaging and reduce food losses that otherwise occur at the production and retail stages (Galli \& Brunori, 2015; Tasca et al., 2017). Similarly, short supply chains can be conducive to environmentally sounder practices, e.g. due to the closer or even direct contact between consumers and the producers. And for a successful circular economy, spatial location can also be one factor (among others) (Kiss et al., 2019). Still, it is not possible to generalise, and local food does not automatically reduce negative environmental externalities (Paciarotti \& Torregiani, 2021).

\section{Social sustainability}

\section{Food security and resilience}

Apart from environmental impacts of local food systems, for sustainability also social aspects matter. In this regard, an important consideration is the question if local food systems can ensure food security and if they are more resilient ${ }^{1}$. Given the differences in agro-ecological and climate conditions across localities and regions, and given vastly different population densities (urbanisation), it is perhaps not surprising that there is

\footnotetext{
${ }^{1}$ While food security could be categorised differently, we see food security as being a part of broad-based benefits that sustainable food systems should bring to society, i.e. that it is part of the social dimension of sustainability (Nguyen, 2018).
} 
Table 1 The performance of local food systems on key sustainability criteria

\begin{tabular}{lllll}
\hline GHG & $\begin{array}{l}\text { Other } \\
\text { emissions }\end{array}$ & $\begin{array}{l}\text { Food } \\
\text { security }\end{array}$ & $\begin{array}{l}\text { Other } \\
\text { social }\end{array}$ & Economic \\
\hline
\end{tabular}

Costello et al., 2021

Takacs \& Borrion, 2020

Majewski et al., 2020

Bellmann, 2020

Ritchie, 2020

Kinnunen et al., 2020

Bell \& Horvath, 2020

Malak-Rawlikowska et al., 2019

Kiss et al., 2019

Vittersø et al., 2019

Mancini et al., 2019

Rogissart et al., 2019

Sandström et al., 2018

Deppermann et al., 2018

Fraser \& Balcombe, 2018

Schmitt et al., 2017

Clapp, 2017

Notarnicola et al., 2017

Tasca et al., 2017

Karg et al., 2016

de Fazio, 2016

Schwarz et al., 2016

Pradhan et al., 2015

Puma et al., 2015

Migliore et al., 2015

Low et al., 2015

Pradhan et al., 2014

D’Odorico et al., 2014

Kneafsey et al., 2013

Galli \& Brunori, 2015

Webb et al., 2013

Aubry \& Kebir, 2013

Campbell, 2012

Mundler \& Rumpus, 2012

Sexton, 2009

Coley et al., 2009

Rask \& Rask, 2011

DeSoucey, 2012

Carlsson-Kanyama \& González, 2009 no

uncertain

uncertain

some

yes

no

no

no

no

no

uncertain

uncertain

uncertain

uncertain

uncertain

uncertain

uncertain

uncertain

uncertain

uncertain

no

uncertain

no

uncertain

uncertain

uncertain

uncertain

some

no

some

yes

no

uncertain

uncertain yes

yes

yes

no

some

some

yes

no

some

uncertain

no

uncertain

some

uncertain

uncertain

no

no

no

no

uncertain

uncertain

some

yes

uncertain

uncertain

yes

some

uncertain

uncertain

no

uncertain

uncertain

uncertain

uncertain

uncertain

uncertain

no

uncertain uncertain

uncertain 
Table 1 (continued)

\begin{tabular}{|c|c|c|c|c|c|}
\hline & $\begin{array}{l}\text { GHG } \\
\text { emissions }\end{array}$ & $\begin{array}{l}\text { Other } \\
\text { environm. }\end{array}$ & $\begin{array}{l}\text { Food } \\
\text { security }\end{array}$ & $\begin{array}{l}\text { Other } \\
\text { social }\end{array}$ & Economic \\
\hline Edwards-Jones, 2010 & uncertain & uncertain & & uncertain & \\
\hline Peters et al., 2009 & uncertain & uncertain & uncertain & uncertain & \\
\hline
\end{tabular}

Note: Following our qualitative assessment of the papers, the cells in the table answer the question whether local food systems and short supply chains contribute to more sustainability in the corresponding category (yes), do not contribute to more sustainability (no), may do so for some products or regions but not for others (uncertain), or may do so only for some sub-categories (some). Studies that are limited in scope (e.g. to organic lettuce in Lombardy or oranges in the USA) may produce more specific results than reviews that cover a broad range of products and regions. For this review, we did a systematic search on "Scholar", an academic search engine that provides an effective way to access peer-reviewed papers and grey literature (Dixon et al., 2010; Shultz, 2007). We started from an existing set of literature and defined the following two search strings to do a systematic search for literature published since 2006 (food OR agricultural OR "agri-food" "short supply" OR "short value" OR "local supply" OR "local value" chain OR chains OR system OR systems sustainable OR sustainability OR footprint OR carbon OR emissions) and (food OR agricultural "selfsufficiency" OR "self-sufficient" OR autarky OR autarkic OR foodshed OR foodsheds). We sorted the results by relevance and then retrieved the papers based on their substance, following an evaluation of their titles and abstracts. We continued with the evaluation until the bulk of search results were no longer relevant. We also excluded books as well as articles in predatory journals (Eriksson \& Helgesson, 2017; Koerber et al., 2020), but we included grey literature from academic institutions and think-tanks. We complemented the results through ad hoc searches and snowballing (Badampudi et al., 2015). While this is not an exhaustive review of the literature, it gives a representative overview of the findings in the most relevant literature on local food systems and short supply chains, ranging from individual case studies and modelling exercises to reviews

agreement in the literature that local food systems generally cannot ensure food security and that resilience is enhanced by strategically diversifying the food supply via trade rather than by limiting it to local production (Table 1 ).

In fact, less than one-third of the global population would be capable of meeting its food demand from local crop production (even if food waste is reduced, yield gaps are closed, and diets are adjusted to more efficient crop mixes), and only 11-28\% could fulfil their demand for specific crops within a $100-\mathrm{km}$ radius. For $26-64 \%$ of the population, that distance is even greater than $1000 \mathrm{~km}$, with substantial variation between different regions and crops (Kinnunen et al., 2020). For rice and maize, only $10 \%$ of the global population can theoretically fulfil their demand within $100 \mathrm{~km}$, while for other cereals and pulses less than $25 \%$ can meet their demand in foodsheds with such a relatively small radius (Verstegen, 2020). Even if foodsheds were defined at a transnational level, large parts of the globe would still depend on trade to feed themselves (Kinnunen et al., 2020). If not just staple food or calories are considered but all the nutrients, the foodsheds required for a balanced diet become even bigger (Costello et al., 2021).

Only about 400 million people worldwide live in an area where locally (within less than $100 \mathrm{~km}^{2}$ ) enough varieties of the food groups are produced to sustain their existing dietary compositions. Even at a continental scale, the number of food self-sufficient people increases only to around 3.3 billion (Pradhan et al., 2014). This shows the importance of international trade and global products in meeting food demands and ensuring food security (Karg et al., 2016; Pradhan et al., 2014; Schmitt et al., 2017). For instance, in Europe, international trade helped safeguard food security during the heat wave in 2003 (Puma et al., 2015). 
On the other hand, countries can have legitimate concerns about risks associated with excessive reliance on trade for their food supplies (Clapp, 2017). Food security can be threatened not only by regional climate-related shocks, but also by price volatility and changes in global markets (D'Odorico et al., 2014). Therefore, while trade allows mitigating the impact of local variability of supply, to increase the resilience of the system overall and to ensure food security also in times of crises, a balance has to be struck between relying on local food production and suitably diversified trade in food products.

Similarly, regarding the affordability of food, there is little evidence that short supply chains improve consumers' access to affordable healthy food (Galli \& Brunori, 2015). For instance in Europe, local food systems can increase prices of livestock products due to the shortening of feed supply chains and concomitant increases in production costs (Deppermann et al., 2018). In contrast, global food products present substantial advantages in terms of affordability, in particular for middle and low-income consumers (Schmitt et al., 2017).

\section{Other social impacts}

When it comes to other social impacts, the literature mentions several benefits of local food systems, particularly aspects of care and links to the territory (Schmitt et al., 2017). When production and processing occurs locally, it is influenced by local heritage and consumption patterns (Galli et al., 2015), contributes to the revitalisation of rural areas, provides new job opportunities especially for young people, boosts farmers' self-esteem and helps create relationships between city and countryside (Mancini et al., 2019; Mundler \& Laughrea, 2016), which can promote community development (Karg et al., 2016). The stability of local food systems may be overestimated, though, as there can be substantial flux of actors and social networks can decay over time (Brinkley et al., 2021).

However, in the literature, social benefits are more often linked to short food supply chains rather than to local food systems as such. It is short supply chains that can favour the interaction and connection between farmers and consumers and thereby promote the development of trust and social capital that in turn can generate a sense of local identity and community and contribute to social inclusion (Galli \& Brunori, 2015; Kiss et al., 2019; Kneafsey et al., 2013; Vittersø et al., 2019). Short supply chains can also promote the social and professional recognition of farmers (Mundler \& Laughrea, 2016).

\section{Economic sustainability}

\section{Benefits for producers}

Economic aspects of food systems are also important in the context of sustainability. As the previous sections already have shown, local food systems do not necessarily provide consumers with more affordable food, but they may contribute to rural development and help create employment, which benefits rural populations. In this section, the focus is on whether local food systems help farmers increase their viability and profitability. 
In the literature, also economic benefits are more often linked to short supply chains than to local food systems as such. And while consumers can have a greater willingness to pay for local food (Printezis et al., 2019), there are indications that short supply chains can result in better prices for producers and that farmers can appropriate more added value and thereby improve their income, e.g. by selling part of their output in their own outlets to reduce costs while gaining reputation (Malak-Rawlikowska et al., 2019; Mancini et al., 2019; Schmitt et al., 2017). To the extent that they are successful and increase local financial flows, local food systems can also have positive multiplier effects on local economies and allow the exploitation of synergies with the tourism sector (Kneafsey et al., 2013; Mancini et al., 2019). The contribution of the food system to local economies of rural areas is limited, though, and other opportunities to drive rural change may be greater, such as the provision of better medical and transport services and of faster internet (OECD, 2020).

However, short supply chains usually rely on the commercialisation of high-quality agricultural products and on consumers' readiness to pay more for products they know and trust because they understand the "real" costs of production (de Fazio, 2016; Galli $\&$ Brunori, 2015). Therefore, the demand for local products may be limited by the number of consumers who can afford to pay higher prices, or who are willing to do so, and eventually sales may stagnate due to plateauing consumer interest (Low et al., 2015). Due to the small scales of local systems and the sourcing of inputs through shorter supply chains, local producers may also be constrained in how much they can reduce their production costs (Deppermann et al., 2018; Kneafsey et al., 2013).

\section{Trade benefits}

For instance, in the European Union (EU), agricultural products account for about $8 \%$ of the Union's total international trade, and over the last 10 years, its trade in agricultural products grew on average 5\% per year, with exports growing faster than imports (EC, 2020b). In particular, agri-food products with protected "geographical indications" are profitable as their sales value is on average double that for similar but uncertified products - and more than $20 \%$ of their total worth of about $€ 75$ billion are generated through exports outside the Union (EC, 2020c). In contrast, little more than $50 \%$ of the products with geographical indications are sold within the country where they are produced (AND, 2021), and it is safe to assume that only a fraction of that is sold locally in the area where they are produced.

Serving local markets can benefit certain farmers, especially those who are located close to urban areas where there are enough consumers with the purchasing power and the willingness to pay for local premium products. However, other producers benefit from being able to sell quality products on regional and global markets, and they would suffer if they were limited to producing for their local area.

\section{Conclusions}

In this review, we defined local food systems and assessed their sustainability with respect to their environmental, social and economic dimension. We confirmed that "local food" cannot be equated with "sustainable food" (Kiss et al., 2019). No simple 
statement on the sustainability of different food systems is possible as sustainability is determined by many factors. This is particularly relevant for decision-makers to understand, given that consumers may rely on an "our own country is best" heuristic when assessing the sustainability of food products, which can result in systematic mistakes (Lazzarini et al., 2017).

In terms of environmental sustainability, in particular, the notion that "food miles" could be used as an indicator for a product's carbon footprint has been widely rejected in the literature; a food product's carbon footprint depends much more on land use, production efficiencies, economies of scale in transport, or whether it is plant-based, than on the distance it travelled. In terms of social sustainability, local food systems cannot ensure food security alone, but they can contribute to rural development and a sense of community. Finally, in terms of economic sustainability, local food systems can benefit certain farmers, but an indiscriminate focus on local food systems would hurt producers who rely on trade and successfully supply international markets.

As this review has shown, no simple statement on the sustainability of different food systems is possible as sustainability is determined by many factors. Therefore, promoting local food as being inherently more sustainable or better for the climate could lead to outcomes that may not be in line with the professed objectives of policy-makers, or even contrary to some aspects of sustainability. In the EU, this will have to be taken into account by member states at the time of choosing the best policy mix for their national "CAP strategic plans" to achieve the objectives of the EU's common agricultural policy (EC, 2021). To nevertheless guide consumers' decision-making towards greater sustainability, the sustainability of food products has to be evaluated on a caseby-case basis. Currently, consumers' motivation for buying local food is based on a range of assumptions about non-sensory and credence attributes of such products, or on associations they make between the quality of local food and values they hold (Hasselbach \& Roosen, 2015; Mugera et al., 2017)

In this context, introducing a mandatory labelling scheme that reflects products' performance with regard to different aspects of sustainability could be a solution. Such a scheme could communicate to consumers explicitly which food products (including local food products) perform better on which sustainability criteria. In the European Union, one of the actions foreseen in the European Commission's Farm to Fork Strategy is the development of a "proposal for a sustainable food labelling framework to empower consumers to make sustainable food choices" (EC, 2020a). At a more limited scale - focused mostly on the environmental dimension - such labels are currently being discussed (Poore, 2018) or already implemented as private schemes (Eaternity, 2014), and more relevant data to support such schemes is becoming publicly available (CONCITO, 2021).

Acknowledgements We would like to thank the editor and a reviewer for their helpful comments and for making our discussion of the policy implications stronger. Any remaining shortcomings are our responsibility alone.

Code availability Not applicable

Availability of data and material Not applicable 
Author contribution AJS: conceptualization, methodology, investigation, writing; FS: conceptualization, writing.

\section{Declarations}

Ethics approval Not applicable

Consent to participate Not applicable

Consent for publication Not applicable

Disclaimer The information and views set out in this article are those of the authors and do not necessarily reflect the official position of the European Commission.

\section{References}

AND International \& ECORYS. (2021). Study on economic value of EU quality schemes, geographical indications (GIs) and traditional specialities guaranteed (TSGs). European Commission. https://doi.org/ 10.2762/396490.

Aubry, C., \& Kebir, L. (2013). Shortening food supply chains: A means for maintaining agriculture close to urban areas? The case of the French metropolitan area of Paris. Food Policy, 41, 85-93. https://doi.org/10. 1016/j.foodpol.2013.04.006.

Badampudi, D., Wohlin, C., \& Petersen, K. (2015). Experiences from using snowballing and database searches in systematic literature studies. In ACM International Conference Proceeding Series, 27-29Apri (pp. 1-10). https://doi.org/10.1145/2745802.2745818.

Bell, E. M., \& Horvath, A. (2020). Modeling the carbon footprint of fresh produce: effects of transportation, localness, and seasonality on US orange markets. Environmental Research Letters, 15(3), 034040. https:// doi.org/10.1088/1748-9326/ab6c2f.

Bellmann, C. (2020). Privileging Local Food is Flawed Solution to Reduce Emissions (Global Trade Policy Forum). https://www.chathamhouse.org/2020/04/privileging-local-food-flawed-solution-reduceemissions

Benis, K., \& Ferrão, P. (2017). Potential mitigation of the environmental impacts of food systems through urban and peri-urban agriculture (UPA) - a life cycle assessment approach. Journal of Cleaner Production, 140, 784-795. https://doi.org/10.1016/j.jclepro.2016.05.176.

Brinkley, C., Manser, G. M., \& Pesci, S. (2021). Growing pains in local food systems: a longitudinal social network analysis on local food marketing in Baltimore County, Maryland and Chester County, Pennsylvania. Agriculture and Human Values, 1, 3. https://doi.org/10.1007/s10460-021-10199-w.

Campbell, B. (2012). Is eating local good for the climate? Thinking beyond food miles. https://www.ccafs. cgiar.org/blog/eating-local-good-climate-thinking-beyond-food-miles.

Carlsson-Kanyama, A., \& González, A. D. (2009). Potential contributions of food consumption patterns to climate change. The American Journal of Clinical Nutrition, 89(5), 1704S-1709S. https://doi.org/10. 3945/ajcn.2009.26736AA.

Clapp, J. (2017). Food self-sufficiency: Making sense of it, and when it makes sense. Food Policy, 66, 88-96. https://doi.org/10.1016/j.foodpol.2016.12.001.

Coley, D., Howard, M., \& Winter, M. (2009). Local food, food miles and carbon emissions: A comparison of farm shop and mass distribution approaches. Food Policy, 34(2), 150-155. https://doi.org/10.1016/j. foodpol.2008.11.001.

CONCITO. (2021). Ny database gør os klogere på fødevarers klimabelastning. https://translate.google.com/ translate?sl=da\&tl=en \&u=https:/concito.dk/nyheder/ny-database-goer-os-klogere-paa-foedevarersklimabelastning

CoR. (2021). From farm to fork - the local and regional dimension (2021/C 37/04; Opinion). https://eur-lex. europa.eu/legal-content/EN/TXT/?uri=CELEX:52020IR0594

Costello, C., Oveysi, Z., \& McGarvey, R. (2021). Assessment of the Effect of Urban Agriculture on Achieving a Localized Food System Centered on Chicago, IL Using Robust Optimization. Environmental Science \& Technology, acs.est.0c04118. https://doi.org/10.1021/acs.est.0c04118. 
Crippa, M., Solazzo, E., Guizzardi, D., Monforti-Ferrario, F., Tubiello, F. N., \& Leip, A. (2021). Food systems are responsible for a third of global anthropogenic GHG emissions. Nature Food, 2(3), 198-209. https:// doi.org/10.1038/s43016-021-00225-9.

D’Odorico, P., Carr, J. A., Laio, F., Ridolfi, L., \& Vandoni, S. (2014). Feeding humanity through global food trade. Earth's Future, 2(9), 458-469. https://doi.org/10.1002/2014EF000250.

de Fazio, M. (2016). Agriculture and Sustainability of the Welfare: The Role of the Short Supply Chain. Agriculture and Agricultural Science Procedia, 8, 461-466. https://doi.org/10.1016/j.aaspro.2016.02.044.

Deppermann, A., Havlík, P., Valin, H., Boere, E., Herrero, M., Vervoort, J., \& Mathijs, E. (2018). The market impacts of shortening feed supply chains in Europe. Food Security, 10(6), 1401-1410. https://doi.org/10. 1007/s12571-018-0868-2.

DeSoucey, M. (2012). Gastronationalism. In The Wiley-Blackwell Encyclopedia of Globalization. John Wiley \& Sons, Ltd.. https://doi.org/10.1002/9780470670590.wbeog226.

Dixon, L., Duncan, C., Fagan, J. C., Mandernach, M., \& Warlick, S. E. (2010). Finding Articles and Journals via Google Scholar, Journal Portals, and Link Resolvers: Usability Study Results on JSTOR. Reference and User Services Quarterly, 50(2), 170-181. https://doi.org/10.5860/rusq.50n2.

Eaternity. (2014). Eaternity Score: Precise assessments for your foods environmental footprint. https:// eaternity.org/score/

EC. (2014). Support for rural development by the European Agricultural Fund for Rural Development (807/ 2014; Commission Delegated Regulation (EU)). https://eur-lex.europa.eu/eli/reg_del/2014/807/oj

EC. (2020a). A Farm to Fork Strategy for a fair, healthy and environmentally-friendly food system (COM/ 2020/381; Communication). https://eur-lex.europa.eu/legal-content/EN/TXT/?uri=CELEX: 52020DC0381

EC. (2020b). Extra-EU trade in agricultural goods (Statistics Explained). https://ec.europa.eu/eurostat/ statistics-explained/index.php/Extra-EU_trade_in_agricultural_goods

EC. (2020c). Geographical Indications - a European treasure worth $€ 75$ billion (Press Release). https://ec. europa.eu/commission/presscorner/detail/en/IP 20683

EC. (2021). CAP strategic plans (Key Policies). https://ec.europa.eu/info/food-farming-fisheries/key-policies/ common-agricultural-policy/cap-strategic-plans en

Edwards-Jones, G. (2010). Does eating local food reduce the environmental impact of food production and enhance consumer health? Proceedings of the Nutrition Society, 69(4), 582-591. https://doi.org/10.1017/ S0029665110002004.

ENRD. (2020). Promoting local food through online platforms: experiences across the EU. https://enrd.ec. europa.eu/news-events/news/promoting-local-food-through-online-platforms-experiences-across-eu_en

Eriksson, S., \& Helgesson, G. (2017). The false academy: predatory publishing in science and bioethics. Medicine, Health Care and Philosophy, 20(2), 163-170. https://oi.org/10.1007/s11019-016-9740-3.

EU. (2013). Support for rural development by the European Agricultural Fund for Rural Development (1305/2013; Regulation (EU)). https://eur-lex.europa.eu/eli/reg/2013/1305/oj

Fraser, I., \& Balcombe, K. (2018). Wrapped in the Flag: Food Choice and Country of Origin Labelling. EuroChoices, 17(3), 37-42. https://doi.org/10.1111/1746-692X.12189.

Galli, F., \& Brunori, G. (2015). Short food supply chains as drivers of sustainable development (Evidence Document). https://orgprints.org/28858/

Galli, F., Bartolini, F., Brunori, G., Colombo, L., Gava, O., Grando, S., \& Marescotti, A. (2015). Sustainability assessment of food supply chains: an application to local and global bread in Italy. Agricultural and Food Economics, 3(1), 21. https://doi.org/10.1186/s40100-015-0039-0.

Glauber, J., Laborde, D., Martin, W., \& Vos, R. (2020). COVID-19: Trade restrictions are worst possible response to safeguard food security. https:/www.ifpri.org/blog/covid-19-trade-restrictions-are-worstpossible-response-safeguard-food-security

Hasselbach, J. L., \& Roosen, J. (2015). Consumer Heterogeneity in the Willingness to Pay for Local and Organic Food. Journal of Food Products Marketing, 21(6), 608-625. https://doi.org/10.1080/10454446. 2014.885866.

Karg, H., Drechsel, P., Akoto-Danso, E., Glaser, R., Nyarko, G., \& Buerkert, A. (2016). Foodsheds and City Region Food Systems in Two West African Cities. Sustainability, 8(12), 1175. https://doi.org/10.3390/ su8121175.

Kinnunen, P., Guillaume, J. H. A., Taka, M., D’Odorico, P., Siebert, S., Puma, M. J., Jalava, M., \& Kummu, M. (2020). Local food crop production can fulfil demand for less than one-third of the population. Nature Food, 1(4), 229-237. https://doi.org/10.1038/s43016-020-0060-7.

Kiss, K., Ruszkai, C., \& Takács-György, K. (2019). Examination of Short Supply Chains Based on Circular Economy and Sustainability Aspects. Resources, 8(4), 161. https://doi.org/10.3390/resources8040161. 
Kneafsey, M., Venn, L., Schmutz, U., Balázs, B., Trenchard, L., Eyden-Wood, T., Bos, E., Sutton, G., \& Blackett, M. (2013). Short food supply chains and local food systems in the EU (EUR 25911 EN; JRC Scientific and Policy Reports). https://doi.org/10.2791/88784.

Koerber, A., Starkey, J. C., Ardon-Dryer, K., Cummins, R. G., Eko, L., \& Kee, K. F. (2020). A qualitative content analysis of watchlists vs safelists: How do they address the issue of predatory publishing? Journal of Academic Librarianship, 46(6), 102236. https://doi.org/10.1016/j.acalib.2020.102236.

Lazzarini, G. A., Visschers, V. H. M., \& Siegrist, M. (2017). Our own country is best: Factors influencing consumers' sustainability perceptions of plant-based foods. Food Quality and Preference, 60, 165-177. https://doi.org/10.1016/j.foodqual.2017.04.008.

Low, S. A., Adalja, A., Beaulieu, E., Key, N., Martinez, S., Melton, A., Perez, A., Ralston, K., Stewart, H., Suttles, S., Vogel, S., \& Jablonski, B. B. R. (2015). Trends in U.S. Local and Regional Food Systems. https:/www.ers.usda.gov/publications/pub-details/?pubid=42807

Macdiarmid, J. I. (2014). Seasonality and dietary requirements: Will eating seasonal food contribute to health and environmental sustainability? Proceedings of the Nutrition Society, 73(3), 368-375. https://doi.org/ $10.1017 /$ S0029665113003753.

Majewski, E., Komerska, A., Kwiatkowski, J., Malak-Rawlikowska, A., Wąs, A., Sulewski, P., Gołaś, M., Pogodzińska, K., Lecoeur, J.-L., Tocco, B., Török, Á., Donati, M., \& Vittersø, G. (2020). Are Short Food Supply Chains More Environmentally Sustainable than Long Chains? A Life Cycle Assessment (LCA) of the Eco-Efficiency of Food Chains in Selected EU Countries. Energies, 13(18), 4853. https://doi.org/10. 3390/en13184853.

Malak-Rawlikowska, A., Majewski, E., Wąs, A., Borgen, S. O., Csillag, P., Donati, M., Freeman, R., Hoàng, V., Lecoeur, J.-L., Mancini, M. C., Nguyen, A., Saïdi, M., Tocco, B., Török, Á., Veneziani, M., Vittersø, G., \& Wavresky, P. (2019). Measuring the Economic, Environmental, and Social Sustainability of Short Food Supply Chains. Sustainability, 11(15), 4004. https://doi.org/10.3390/su11154004.

Mancini, M., Menozzi, D., Donati, M., Biasini, B., Veneziani, M., \& Arfini, F. (2019). Producers' and Consumers' Perception of the Sustainability of Short Food Supply Chains: The Case of Parmigiano Reggiano PDO. Sustainability, 11(3), 721. https://doi.org/10.3390/su11030721.

Markuszewska, A., Prior, A., Strano, A., Bálint, B., Midoux, B., Bros, C., Koutsaftaki, C., Jochum, C., Buffet, C., McGlynn, D., Bravo, F. del, Valtari, H., Czaja, J., Saalasto, P., Töyli, P., Kokovkin, R., Redman, M., Mazili, S. R., Silm, S., ... Hudson, T. (2012). EU rural review (No. 12; EU Rural Review). https://op. europa.eu/en/publication-detail/-/publication/42858164-67b1-49df-920b-349b25e55064

Migliore, G., Schifani, G., \& Cembalo, L. (2015). Opening the black box of food quality in the short supply chain: Effects of conventions of quality on consumer choice. Food Quality and Preference, 39, 141-146. https://doi.org/10.1016/j.foodqual.2014.07.006.

Mugera, A., Burton, M., \& Downsborough, E. (2017). Consumer Preference and Willingness to Pay for a Local Label Attribute in Western Australian Fresh and Processed Food Products. Journal of Food Products Marketing, 23(4), 452-472. https://doi.org/10.1080/10454446.2015.1048019.

Mundler, P., \& Laughrea, S. (2016). The contributions of short food supply chains to territorial development: A study of three Quebec territories. Journal of Rural Studies, 45, 218-229. https://doi.org/10.1016/j. jrurstud.2016.04.001.

Mundler, P., \& Rumpus, L. (2012). The energy efficiency of local food systems: A comparison between different modes of distribution. Food Policy, 37(6), 609-615. https://doi.org/10.1016/j.foodpol.2012. 07.006 .

Nguyen, H. (2018). Sustainable food systems (No. CA2079EN; FAO Brief). http://www.fao.org/3/ca2079en/ CA2079EN.pdf

Notarnicola, B., Sala, S., Anton, A., McLaren, S. J., Saouter, E., \& Sonesson, U. (2017). The role of life cycle assessment in supporting sustainable agri-food systems: A review of the challenges. Journal of Cleaner Production, 140, 399-409. https://doi.org/10.1016/j.jclepro.2016.06.071.

OECD. (2020). Rural Well-being: Geography of Opportunities (OECD Rural Studies). Organisation for Economic Cooperation and Development. https://doi.org/10.1787/d25cef80-en.

Paciarotti, C., \& Torregiani, F. (2021). The logistics of the short food supply chain: A literature review. In Sustainable Production and Consumption (Vol. 26, pp. 428-442). Elsevier B.V. https://doi.org/10.1016/j. spc.2020.10.002.

Peters, C. J., Bills, N. L., Wilkins, J. L., \& Fick, G. W. (2009). Foodshed analysis and its relevance to sustainability. Renewable Agriculture and Food Systems, 24(1), 1-7. https://doi.org/10.1017/ S1742170508002433.

Poore, J. (2018). We label fridges to show their environmental impact - why not food? The Guardian. https:// www.theguardian.com/environment/2018/oct/10/we-label-fridges-to-show-their-environmental-impactwhy-not-food 
Pradhan, P., Lüdeke, M. K. B., Reusser, D. E., \& Kropp, J. P. (2014). Food self-sufficiency across scales: How local can we go? Environmental Science and Technology, 48(16), 9463-9470. https://doi.org/10. 1021/es5005939.

Pradhan, P., Fischer, G., van Velthuizen, H., Reusser, D. E., \& Kropp, J. P. (2015). Closing Yield Gaps: How Sustainable Can We Be? PLOS ONE, 10(6), e0129487. https://doi.org/10.1371/journal.pone.0129487.

Printezis, I., Grebitus, C., \& Hirsch, S. (2019). The price is right!? A meta-regression analysis on willingness to pay for local food. PLOS ONE, 14(5), e0215847. https://doi.org/10.1371/journal.pone.0215847.

Puigdueta, I., Aguilera, E., Cruz, J. L., Iglesias, A., \& Sanz-Cobena, A. (2021). Urban agriculture may change food consumption towards low carbon diets. Global Food Security, 28, 100507. https://doi.org/10.1016/j. gfs.2021.100507.

Puma, M. J., Bose, S., Chon, S. Y., \& Cook, B. I. (2015). Assessing the evolving fragility of the global food system. Environmental Research Letters, 10(2), 024007. https://doi.org/10.1088/1748-9326/10/2/024007.

Rask, K. J., \& Rask, N. (2011). Economic development and food production-consumption balance: A growing global challenge. Food Policy, 36(2), 186-196. https://doi.org/10.1016/j.foodpol.2010.11.015.

Ritchie, H. (2020). You want to reduce the carbon footprint of your food? Focus on what you eat, not whether your food is local (Our World in Data). https://ourworldindata.org/food-choice-vs-eating-local

Ritchie, H., \& Roser, M. (2020). Environmental impacts of food production (Our World in Data). https:// ourworldindata.org/environmental-impacts-of-food

Rogissart, L., Foucherot, C., \& Bellassen, V. (2019). Food policies and climate: a literature review. https:// www.i4ce.org/download/food-policies-and-climate-a-literature-review/

Sandström, V., Valin, H., Krisztin, T., Havlík, P., Herrero, M., \& Kastner, T. (2018). The role of trade in the greenhouse gas footprints of EU diets. Global Food Security, 19, 48-55. https://doi.org/10.1016/j.gfs. 2018.08.007.

Schmitt, E., Galli, F., Menozzi, D., Maye, D., Touzard, J. M., Marescotti, A., Six, J., \& Brunori, G. (2017). Comparing the sustainability of local and global food products in Europe. Journal of Cleaner Production, 165, 346-359. https://doi.org/10.1016/j.jclepro.2017.07.039.

Schreiber, K., Hickey, G. M., Metson, G. S., Robinson, B. E., \& MacDonald, G. K. (2021). Quantifying the foodshed: a systematic review of urban food flow and local food self-sufficiency research. Environmental Research Letters, 16(2), 023003. https://doi.org/10.1088/1748-9326/abad59.

Schwarz, J., Schuster, M., Annaert, B., Maertens, M., \& Mathijs, E. (2016). Sustainability of Global and Local Food Value Chains: An Empirical Comparison of Peruvian and Belgian Asparagus. Sustainability, 8(4), 344. https://doi.org/10.3390/su8040344.

Sexton, S. (2009). Does Local Production Improve Environmental and Health Outcomes? ARE Update, 13(2), 5-8 https:/giannini.ucop.edu/publications/are-update/issues/2009/13/2/does-local-production-imp/.

Shultz, M. (2007). Comparing test searches in PubMed and Google Scholar. Journal of the Medical Library Association, 95(4), 442-445. https://doi.org/10.3163/1536-5050.95.4.442.

Takacs, B., \& Borrion, A. (2020). The Use of Life Cycle-Based Approaches in the Food Service Sector to Improve Sustainability: A Systematic Review. Sustainability, 12(9), 3504. https://doi.org/10.3390/ su12093504.

Tasca, A. L., Nessi, S., \& Rigamonti, L. (2017). Environmental sustainability of agri-food supply chains: An LCA comparison between two alternative forms of production and distribution of endive in northern Italy. Journal of Cleaner Production, 140, 725-741. https://doi.org/10.1016/j.jclepro.2016.06.170.

Thomson, A., \& Metz, M. (1998). Implications of Economic Policy for Food Security (No. 40; Training Materials for Agricultural Planning). http://www.fao.org/3/x3936e/X3936E00.htm

Verstegen, J. A. (2020). The local versus global food debate. Nature Food, 1(4), 198-199. https://doi.org/10. 1038/s43016-020-0062-5.

Vittersø, G., Torjusen, H., Laitala, K., Tocco, B., Biasini, B., Csillag, P., de Labarre, M. D., Lecoeur, J.-L., Maj, A., Majewski, E., Malak-Rawlikowska, A., Menozzi, D., Török, Á., \& Wavresky, P. (2019). Short Food Supply Chains and Their Contributions to Sustainability: Participants' Views and Perceptions from 12 European Cases. Sustainability, 11(17), 4800. https://doi.org/10.3390/su11174800.

Webb, J., Williams, A. G., Hope, E., Evans, D., \& Moorhouse, E. (2013). Do foods imported into the UK have a greater environmental impact than the same foods produced within the UK? International Journal of Life Cycle Assessment, 18(7), 1325-1343. https://doi.org/10.1007/s11367-013-0576-2.

Publisher's note Springer Nature remains neutral with regard to jurisdictional claims in published maps and institutional affiliations. 